\title{
横流式沈殿池における密度流の発生域の挙動 \\ BEHAVIOR OF A GENERATING ZONE OF DENSITY CURRENTS IN RECTANGULAR SETTLING TANKS
}

\section{1.まえがき}

横流式沈殿池の除去率は, 一般に overflow rate の理 論から与えられる值よりも著しく低いことが知られ, 理 由として池内の乱流拡散, 短絡流, 沈殿物の巻き上げな どが考えられている。

このうち, 流入状況が不均一なときに見られる左右の 偏流による除去率の低下は, 流速の異なる各部分につい てそれぞれ overflow rate を考えることにより説明さ れ, 流入水と池内水の温度差あるいは濁度差によって発 生する密度流のような鉛直方向の流れの偏りは, 掃流や 巻き上げにより除去率を低下しうることが知られてい $る^{1), 2)}$ 。

沈殿池内密度流の発生に関する従来の研究は, 中川 ${ }^{3)}$ および粟谷・楠田 ${ }^{4}$ らにより報告されている。前者は未 定実験パラメーターを含むものであり, 後者は沈殿池内 の流れを完全流体と考え, 鉛直流速を無視して取扱って いるので，いずれも密度流発生に関する実際の現象を十 分説明するものとはいいがたい。

著者らは, 特に流入水と池内水の密度差がかなり大き く, 流入水が整流壁通過直後に急速に上昇し鉛直プリュ 一ムを形成する場合 (図一1 参照) には, この鉛直プリ ニームが池内全体にわたる密度流を形成する最大の要因 となると考えられるので, このプリュームの発生機構に ついて解析的, 実験的検討を加えている。

その結果，与えられた流入条件に対して発生する密度 流を算定するための基礎として，渗出を伴う壁面の抵 抗, 流速および質量欠損分布, 混合状態, 密度界面より の連行などについて一連の結論を得ることができた。

類似した現象に，鉛直プリュームや鉛直熱対流などが ある。前者については, 上く知られる上うに分布形に相

* 正会員 工博 九州大学教授 工学部水工土木教窒

** 正会員 工修 九州大学助手 工学部水工士木教室
粟 谷 陽 一**金子 新** By Yöichi AWAYA and Arata KANEKO

似が存在することより基礎偏微分方程式を分布形に対す る常微分方程式に変換して解を得ている。後者は, 固体 壁抵抗のため分布形に相似が存在しない。そのため, 分 布関数形を 2 個のパラメーター(たとえば,最大流速と噴 流幅）で仮定し, 運動量および質量欠損の保存を考え, パラメーターに対する常微分方程式に変換し, それらの 鉛直方向変化が求められている ${ }^{5)}$ 。

一方, 渗出を伴う固体壁上の抵抗は, わずかの渗出に よって著しく減少することが航空工学の分野で知られて いる6)。

ここで対象とする現象も, 整流壁から絶えず流入水の 渗出があるため, 整流壁上の抵抗は無視できるものとし

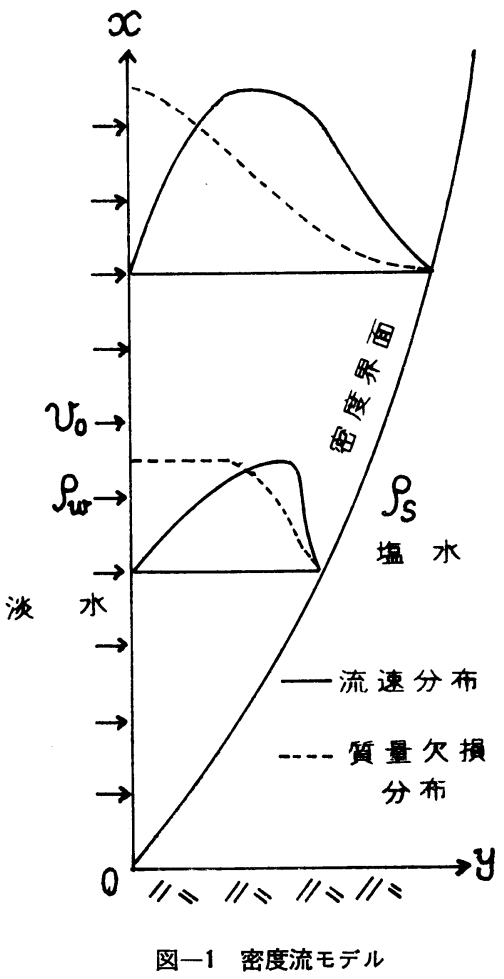


て議論を進めている。ところが，整流壁よりの渗出のた め,プリュームが上昇するにつれ乱流拡散が顕 著にな り, 密度界面よりの連行量も増加し, 流速および質量欠 損分布が図一1 に例示寸るように変わる。このため, 分 布形に相似が存在せず，鉛直プリュームに打けるように 分布関数形を基礎式より直接求めることができない。

プリュームの上昇による分布形の変化を考え，分布形 を 3 個のパラメーターで仮定し, 基礎式にエネルギー式 を加え，鉛直熱対流と同じ解析がなされている。

また, 池底付近の乱流拡散が無視できるほど小さい領 域に対する解およびプリュームが上昇して乱流拡散が十 分発達した時の解が同じく与えられている。

解析の結果, 特に壁面より渗出を伴う場合, 渗出のな い境界層にくらべて Karman 定数が顕著に減少し，壁 面抵抗を無視しても実測值をほぼ説明できることが知ら れた。これにより, 流入部直後における水平密度流の初 期条件を定めることができる。

\section{2. 理 論解析}

\section{（1） 完全流体の解}

乱れおよび粘性を考えるまえに，最も解析の容易な完 全流体の場合について考察し流況の概要を把握する。こ の解は池底付近の乱流拡散の弱い領域におおる現象を説 明することができる。沈殿池流入部の整流壁は，抵抗の 十分大きな渗透壁と考え, 流れは哚さ方向に一様な流速 で壁より渗出するものとする。

池内水に比べて流入水の密度が小さい場合を考え, 図 -1 に示すように流入整流壁に沿って鉛直上向きに $x$ 軸, 池底に沿って下流方向に $y$ 軸をとる。 $x, y$ 方向の 流速成分をそれぞれ $u, v$ とする。流入水の密度が池内 水より大きい時は，流れが上下いれかわりになるだけで 現象としてはほとんど同じである。

壁面プリューム内部にも外部の静水圧と同じ圧力分布 を仮定し，密度界面の混合がなく壁面プリューム内部は すべて流入水の密度 $\rho_{\boldsymbol{w}}$ になっていることを考えれば, 方向の完全流体運動方程式は,

$$
u \frac{\partial u}{\partial x}+v \frac{\partial u}{\partial y}=\varepsilon_{0} g
$$

また，

$$
p=p_{b}-\rho_{s} g x
$$

ただし， $\varepsilon_{0}=\left(\rho_{s}-\rho_{w}\right) / \rho_{w}, \rho_{s}, \rho_{w}$ は，それぞれ池内水 (塩水), 流入水 (淡水) の密度, $p_{b}$ は池底の圧力, $g$ は 重力加速度である。

二次元連続の式は次式で与えられる。

$$
\frac{\partial u}{\partial x}+\frac{\partial v}{\partial y}=0 .
$$

完全流体の場合密度界面での混合はなく, 密度界面は 一つの流線を表わす。

流れ関数 廿を用いると，式 (1)，(3) の解は式 (4) で与えられる。式（4）は特解であるが，別に整流壁面 と上昇するプリューム横断面間との流量と運動量の保存 より同様の結果を導いている。

$$
\psi=-v_{0} x+\frac{\varepsilon_{0} g}{2 v_{0}} y^{2}
$$

ここに, $v_{0}$ は一様流入流速である。

式 (4) より $x, y$ 方向の流速はそれぞれ次式となる。

$$
\begin{aligned}
& u=\frac{\partial \psi}{\partial y}=\frac{\varepsilon_{0} g}{v_{0}} y \\
& v=-\frac{\partial \psi}{\partial x}=v_{0}
\end{aligned}
$$

式（4）において $\psi=0$ と寸れば密度界面の形状が得 られる。

$$
y_{c}=\sqrt{\frac{2 v_{0}^{2}}{\varepsilon_{0} g} x}
$$

ここに， $y_{c}$ は噴流幅である。

関係諸量を次のように無次元化する。

$$
\left.\begin{array}{l}
\xi=\frac{\varepsilon_{0} g x}{v_{0}^{2}}, \quad \eta=\frac{\varepsilon_{0} g y}{v_{0}^{2}}, \quad \eta_{c}=\frac{\varepsilon_{0} g y_{c}}{v_{0}{ }^{2}} \\
U=\frac{u}{v_{0}}, \quad V=\frac{v}{v_{0}}
\end{array}\right\}
$$

式（8）を式 (5)，(6)，(7) に代入すればそれぞれ次 式を得る。

$$
U=\eta, \quad V=1, \quad \eta_{c}=\sqrt{2 \xi}
$$

図一2 に密度界面の形状と流速分布の概要を示す。

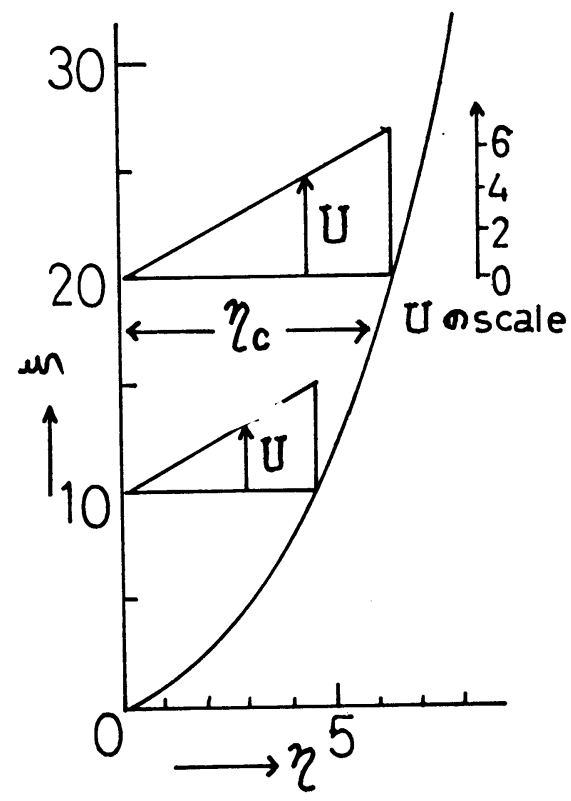

図-2 完全流体 


\section{（2）乱流拡散を考慮した解}

通常の鉛直壁面プリュームの解析においては壁面抵抗 を考える必要があるけれども, 前述のように壁面より渗 出のある場合, 壁面抵抗は著しく減少することが考えら れるので一応これを無視して解析をすすめる。

一般に, 境界層理論に打いて用いられる仮定 $u \gg v$, $\partial / \partial y \gg \partial / \partial x$ を適用し, 混合距離を $l=\kappa y(\kappa$ は Karman 定数) とすれば, 定常流に対する二次元運動方程式は次 式で与えられる。

$$
\begin{aligned}
& \quad u \frac{\partial u}{\partial x}+v \frac{\partial u}{\partial y}=\varepsilon g+\frac{\partial}{\partial y}\left(\kappa^{2} y^{2}\left|\frac{\partial u}{\partial y}\right| \frac{\partial u}{\partial y}\right) \\
& \text { ここに, } \\
& \quad p=p_{b}-\rho_{s} g y \\
& \quad \varepsilon=\left(\rho_{s}-\rho\right) / \rho_{w}
\end{aligned}
$$

である。

ここで, 乱れによる運動量の輸送と質量の輸送を等し いと仮定する Reynolds の相似を適用すれば, 質量欠損 保存則は次式となる。

$$
u \frac{\partial \varepsilon}{\partial x}+v \frac{\partial \varepsilon}{\partial y}=\frac{\partial}{\partial y}\left(\kappa^{2} y^{2}\left|\frac{\partial u}{\partial y}\right| \frac{\partial \varepsilon}{\partial y}\right)
$$

また，二次元連続の式は，

$$
\frac{\partial u}{\partial x}+\frac{\partial v}{\partial y}=0 \cdots
$$

となる。

これらの基䃈方程式の解には，鉛直プリュームなどに おけるような相似な分布形が存在しない。厳密解を求め ることは困難であるが, 流速分布の実測値あるいは完全 流体の解を参照し, 分布形にもら一つの自由度を与え, 境界条件を考えて式（13）のように仮定すれば，ほぼ実 際の分布形を表現しうると思われる。整流壁近傍では, 壁面よりの渗出のため乱れの発達は抑えられ完全流体に 近い直線的な流速分布形をもつと考えられる。このこと は, $0<y<y_{1}$ における正弦関数による流速分布の仮定 に考慮されている（正弦関数は $y=0$ 近傍で直線とな る)。

流速分布：

$$
\begin{aligned}
& 0<y<y_{1} \quad u_{1}=u_{m} \sin \frac{\pi y}{2 y_{1}} \\
& y_{1}<y<y_{1}+y_{2} \quad u_{2}=\frac{u_{m}}{2}\left[1+\cos \frac{\pi\left(y-y_{1}\right)}{y_{2}}\right]
\end{aligned}
$$

質量欠損分布 :

$$
\left.\begin{array}{l}
0<y<y_{1} \quad \varepsilon_{1}=\frac{\varepsilon_{0}}{2}\left[1+\cos \frac{\pi y}{2 y_{1}}\right] \\
y_{1}<y<y_{1}+y_{2} \\
\varepsilon_{2}=\frac{\varepsilon_{0}}{2}\left[1+\cos \frac{\pi\left(y_{1}-y_{1}+y_{2}\right)}{2 y_{2}}\right]
\end{array}\right]
$$

ここに, $u_{m}$ は最大流速， $y_{1}$ は壁面より最大流速点ま

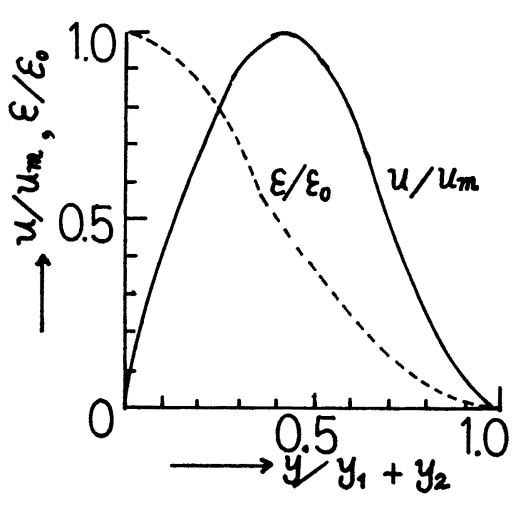

図一3 仮定された分布形の例 $\left(y_{1}: y_{2}=4: 6\right)$

での距離， $y_{2}$ は最大流速点から密度界面までの距離で ある。図一3に $y_{1}: y_{2}=4: 6$ のときの式 (13) による 分布形の例を示す。

式（10）の両辺に $u$ を乗じたものおよび式 (11) を式 (12)を考虑して噴流幅にわたって積分すればそれぞれ次 式を得る。式 (14)，(15)，(16) はそれぞれ運動量，エ ネルギー，質量欠損の保存を示している。

$$
\begin{aligned}
& 2 \int_{0}^{y_{1}+y_{2}} u \frac{\partial u}{\partial x} d y=g \int_{0}^{y_{1}+y_{2}} \varepsilon d y \\
& \frac{3}{2} \int_{0}^{y_{1}+y_{2}} u^{2} \frac{\partial u}{\partial x} d y=g \int_{0}^{y_{1}+y_{2}} \varepsilon u d y \\
& +\int_{0}^{y_{1}+y_{2}} u \frac{\partial}{\partial y}\left(\kappa^{2} y^{2}\left|\frac{\partial u}{\partial y}\right| \frac{\partial u}{\partial y}\right) d y \\
& \int_{0}^{y_{1}+y_{2}} \frac{\partial(\varepsilon u)}{\partial x} d y=\varepsilon_{0} v_{0} \text {...... } \\
& \left.\begin{array}{llll}
y=0 & : u=0 & v=v_{0} & \varepsilon=\varepsilon_{0} \\
y=y_{1}+y_{2}: u=0 & \frac{\partial u}{\partial y}=0 & \varepsilon=0
\end{array}\right\}
\end{aligned}
$$

としている。

式 (14)，(15)，(16) に分布形の仮定（13）を代入す ればそれぞれ次式のようになる。

$$
\begin{aligned}
\left(y_{1}\right. & \left.+\frac{3}{4} y_{2}\right) u_{m} \frac{d u_{m}}{d x}+\frac{1}{2}\left(\frac{d y_{1}}{d x}+\frac{3}{4} \frac{d y_{2}}{d x}\right) u_{m}{ }^{2} \\
= & \frac{\varepsilon_{0} g}{2}\left[\left(1+\frac{2}{\pi} y_{1}\right)+\left(1-\frac{2}{\pi}\right) y_{2}\right] \cdots \cdots(18 \\
\left(\frac{2}{\pi} y_{1}\right. & \left.+\frac{15}{32} y_{2}\right) u_{m} \frac{d u_{m}}{d x} \\
& +\frac{1}{2}\left(\frac{2}{\pi} \frac{d y_{1}}{d x}+\frac{15}{32} \frac{d y_{2}}{d x}\right) u_{m^{2}} \\
= & {\left[\frac{3}{2 \pi} y_{1}+\frac{1}{4}\left(1-\frac{4}{\pi}\right) y_{2}\right] \varepsilon_{0} g } \\
& -\kappa^{2} u_{m}{ }^{2}\left[\frac{\pi^{2}}{4}-\frac{50}{27}+\frac{\pi^{2}}{6 y_{2}{ }^{2}} y_{1}\left(y_{1}+y_{2}\right)\right]
\end{aligned}
$$

$\left[\frac{3}{2 \pi} y_{1}+\left(\frac{1}{4}-\frac{1}{3 \pi}\right) y_{2}\right] u_{m}=v_{0} \cdot x$ 
関係諸量を次のように無次元化する。

$$
\left.\begin{array}{l}
\xi^{*}=\frac{\kappa^{4} \varepsilon_{0} g x}{v_{0}^{2}}, \quad U^{*}=\frac{\kappa^{2} u_{m}}{v_{0}} \\
\eta_{1}{ }^{*}=\frac{\kappa^{2} \varepsilon_{0} g y_{1}}{v_{0}{ }^{2}}, \quad \eta_{2}{ }^{*}=\frac{\kappa^{2} \varepsilon_{0} g y_{2}}{v_{0}{ }^{2}}
\end{array}\right\}
$$

式 (18)，(19)，(20) に式（21）を代入すればそれぞ れ次式を得る。

$$
\begin{aligned}
& \left(\eta_{1}{ }^{*}+\frac{3}{4} \eta_{2}{ }^{*}\right) U^{*} \frac{d U^{*}}{d \xi^{*}}+\frac{1}{2}\left(\frac{d \eta_{1}{ }^{*}}{d \xi^{*}}+\frac{3}{4} \frac{d \eta_{2}{ }^{*}}{d \xi^{*}}\right) U^{* 2} \\
& =\frac{1}{2}\left[\left(1+\frac{2}{\pi}\right) \eta_{1}^{*}+\left(1-\frac{2}{\pi}\right) \eta_{2} *\right] \\
& \left(\frac{2}{\pi} \eta_{1}^{*}+\frac{15}{32} \eta_{2} *\right) U^{*} \frac{d U^{*}}{d \xi^{*}} \\
& +\frac{1}{3}\left(\frac{2}{\pi} \frac{d \eta_{1}{ }^{*}}{d \xi^{*}}+\frac{15}{32} \frac{d \eta_{2}{ }^{*}}{d \xi^{*}}\right) U^{* 2} \\
& =\frac{3}{2 \pi} \eta_{1} *+\frac{1}{4}\left(1-\frac{4}{3 \pi}\right) \eta_{2} * \\
& -U_{*}{ }^{2}\left[\frac{\pi^{2}}{4}-\frac{50}{27}+\frac{\pi^{2}}{6 \eta_{2}{ }^{* 2}} \eta_{1} *\left(\eta_{1} *+\eta_{2}{ }^{*}\right)\right] \\
& {\left[\frac{3}{2 \pi} \eta_{1} *+\left(\frac{1}{4}-\frac{1}{3 \pi}\right) \eta_{2} *\right] U_{*}=\xi *}
\end{aligned}
$$

式 (22)，(23）抢よび式 (24) より $\xi^{*}$ の関数として $U^{*}, \eta_{1}{ }^{*}, \eta_{2}{ }^{*}$ を決定できる。

この結果を式 (13) に代入して $u$ の分布が求安れ ば, vは式 (12) を積分して得られる。

$$
\begin{aligned}
& 0<y<y_{1} \\
& v_{1}=v_{0}-\int_{0}^{y} \frac{\partial u_{1}}{\partial x} d y \\
& y_{1}<y<y_{1}+y_{2} \\
& v_{2}=v_{0}-\int_{0}^{y_{1}} \frac{\partial u_{1}}{\partial x} d y-\int_{y_{1}}^{y} \frac{\partial u_{2}}{\partial x} d y
\end{aligned}
$$

\section{（3）乱れが十分に発達した領域の解}

プリュームが十分に上昇し, 壁面よりの渗出が密度界 面よりの連行量にくらべて無視できるほど小さく, 流速 抢よび質量欠損の分布形が $x$ 方向にほとんど変化しない 領域の解を検討する。この場合も整流壁上の抵抗を無視 すれば, 質量欠損, 運動量および流量の保存則はそれぞ 式 (27)，(28)，(29) となる。

$$
\begin{aligned}
& \int_{0}^{y_{c}} \varepsilon u d y=\varepsilon_{0} v_{0} x \\
& \frac{\partial}{\partial x}\left(\int_{0}^{y_{c}} u^{2} d y\right)=g \int_{0}^{y_{c}} \varepsilon d y \\
& \frac{\partial}{\partial x}\left(\int_{0}^{y_{c}} u d y\right)=E \frac{1}{y_{c}} \int_{0}^{y_{c}} u d y
\end{aligned}
$$

$\varepsilon$ の平均値を $\varepsilon_{m}$, 最大流速を $u_{m}$ とし, 質量欠損, 運動量および流量を変えずに, 流速および質量欠損分布 を矩形分布に置き換えれば, 分布形により決まる定数 $c_{1}$, $c_{2}$ を使用して式 (27)，(28)，(29）はそれぞれ次式のよ うになる。

$$
\begin{aligned}
& c_{1} \varepsilon_{m} u_{m} y_{c}=\varepsilon_{0} v_{0} x \\
& c_{2} \frac{d}{d x}\left(u_{m}^{2} y_{c}\right)=g \varepsilon_{m} y_{c} \\
& \frac{d}{d x}\left(u_{m} y_{c}\right)=E u_{m} \ldots . .
\end{aligned}
$$

式 (30)，(31) より $\varepsilon_{m}$ を消去すれば,

$$
\frac{d}{d x}\left(u_{m}^{2} y_{c}\right)=\frac{\varepsilon_{0} g v_{0}}{c_{1} c_{2}} \frac{x}{u_{m}} \text {. }
$$

式 (32)，(33) より解を求めれば,

$$
\begin{aligned}
& u_{m}=\sqrt[3]{\frac{4}{5 c_{1} c_{2}} \frac{\varepsilon_{0} g v_{0}}{E} x} \\
& y_{c}=\frac{3 E}{4} x \ldots \ldots \ldots \ldots \ldots \ldots \ldots \ldots \ldots \ldots
\end{aligned}
$$

となる。式 (34)，(35) は特解であるが，実測值などと の比較より有意な解であることが後に明らかとなる。

関係諸量を次のように無次元化する。

$$
U_{m}=\frac{u_{m}}{v_{0}}, \quad \xi=\frac{\varepsilon_{0} g x}{v_{0}{ }^{2}}, \quad \eta_{c}=\frac{\varepsilon_{0} g y_{c}}{v_{0}{ }^{2}}
$$

式（36）を式 (34)，(35) に代入して

$$
\begin{aligned}
& U_{m}=\sqrt[3]{\frac{4}{5 c_{1} c_{2} E}} \xi \\
& \eta_{c}=\frac{3 E}{4} \xi \ldots \ldots \ldots \ldots
\end{aligned}
$$

を得る。分布形の仮定式 (13) を適用して $c_{1}, c_{2}$ を決定 すれば,

$$
c_{1}=\frac{2 / \pi+y_{2} / 2 y_{1}}{1+y_{2} / y_{1}}, \quad c_{2}=\frac{1 / 2+3 y_{2} / 8 y_{1}}{1+y_{2} / y_{1}}
$$

となる。十分にプリュームが上昇した領域においては, $y_{1} / y_{2} \ll 1$ となるので結局

$$
c_{1}=2 / \pi, \quad c_{2}=1 / 2
$$

を得る。一方, このときの連行係数 $E$ は, 鉛直プリュ 一ムにおいて得られている值 $E=0.1^{7)}$ を採用すれば,

$$
U_{m}=2.929 \xi^{1 / 3}, \quad \eta_{c}=0.075 \xi \text {. }
$$

を得る。

\section{3. 実験および結果の考察}

\section{（1）実験装置および方法}

流入水と池内水の温度差によって発生する密度流を流 入水に淡水, 池内水に塩水をモデルとして使用し以下の ような模型実験を行い, 密度流流速および塩分濃度分布 を実測した。

模型沈殿池として, 長さ $200 \mathrm{~cm}$, 愊 $10 \mathrm{~cm}$, 深さ 40 $\mathrm{cm}$ の水槽 $[\mathrm{A}]$ と, 深さ $100 \mathrm{~cm}$ で他の諸元の同じ水 槽 $[\mathrm{B}]$ の二種類を使用した。流入水は, 水槽 $[\mathrm{A}]$ によ る実験では流出水をポンプにより循環して用い，水槽 


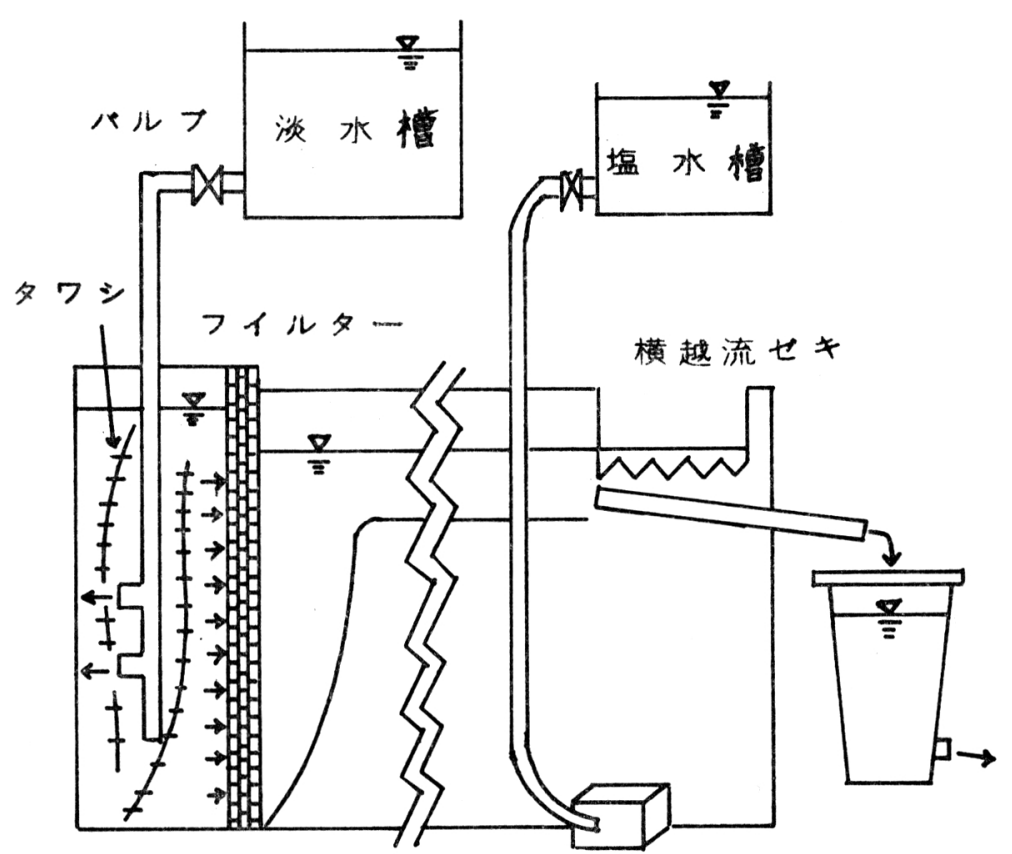

図一4実験装置

沿って上昇するようになった時, すばやく流速および濃度の測定を 行う。流速の測定は，水素気泡法 (Hydrogen Bubble Method) $R$ 上り行い，一定の時間間隔で断続 的に電極上り発生する水素気泡を 写真撮影寸る。写真一1 は, 水素 気泡法による流速の実測例を示し ている。時間間隔は, Timer によ り数種に変換でき, 電極に法直径 $18 \mu$ の白金線を使用した。塩分 濃度は, 四電極伝導度計に上り測 定し記録計に描かせた。塩水は, 密度界面を判定しやすくするため ウラニンで着色している。塩水と 淡水の温度は同じしている。

実験は, 塩水濃度拧よび一様流 入流速を数種変えて行った。表一1 に各実験の諸元を与える。

\section{（2）最大流速と噴流幅}

[B] では容積約 $5 \mathrm{t}$ の淡水貯水槽より連続的に供給して いる。どちらも，塩水の流出を減少させるため流出端は 横越流嚗にし, 実験を通じて水槽底より減少した塩水の 補給がなされている。

水槽 $[\mathrm{A}]$ ，水槽 $[\mathrm{B}]$ では，それぞれ乱流拉散が小さ く完全流体に近い場合，乱流挔散の発達した場合の実験 を行った。図一4に水槽 $[\mathrm{B}]$ を使用した実験装置の概 要が示されている。

模型水槽にあらかじめ塩水を貯留しておき, 布製の整 流壁を通して淡水を水槽内に流入させる。深さ方向にほ ぼ一様な流速で流入させるため, 整流壁の透過抵抗を大 きくし，整流壁前後の水位差を十分に保っている。

実験開始後, 数分の後定常的にプリュームが整流壁に

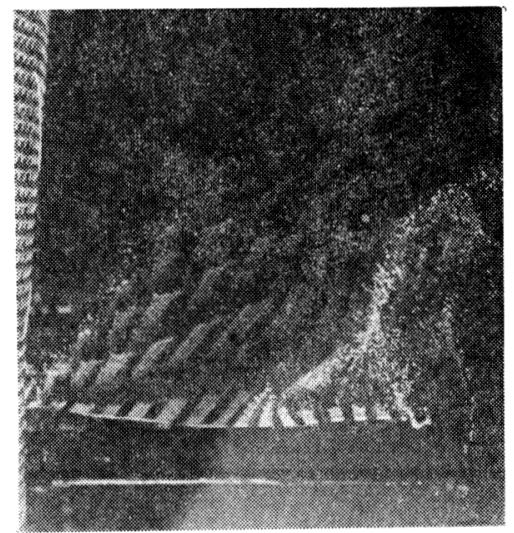

写真一1 水素気泡の写真撮影（水槽 $[\mathrm{A}]$ ）
最大流速および噴流幅の実測值と理論值を，それぞれ 図一5, 図一6 で比較している。

図一5, 図一6 は， $\kappa$ をパラメーターとし，4 種の に対する式 (22)〜 (24) による解析結果と, 同時に完全 流体の解 式 (9) および乱れが十分に発達した領域の解 式(37)，(38) が示されている。

実験值との比較より， 解からはずれ，๘もしだいに増加してゆき乱れが十分に 発達した領域の解に漸近してゆく様子が認められる。こ のことは, 後に連行係数の議論においても示される。実 験範囲内で $\kappa$ の值は最大 0.14 から 0.2 程度であり, 渗出のない普通の境界層に対する $\kappa$ が 0.4 であること

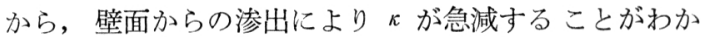

表-1 実験条件

\begin{tabular}{|c|c|c|c|c|}
\hline 実験番号 & 水槽名 & $\begin{array}{c}v_{0} \\
(\mathrm{~cm} / \mathrm{s})\end{array}$ & $\varepsilon_{0}=\frac{\rho_{s}-\rho_{w}}{\rho_{w}}$ & $\frac{v_{0}^{2}}{\varepsilon_{0} g}$ \\
\hline EXP 1 & A & 1.80 & 0.004 & 0.827 \\
\hline 2 & $"$ & 1.48 & 0.003 & 0.745 \\
\hline 3 & $"$ & 1.20 & 0.002 & 0.735 \\
\hline 4 & $"$ & 1.43 & 0.003 & 0.696 \\
\hline 5 & $"$ & 1.52 & 0.004 & 0.589 \\
\hline 6 & " & 1.00 & 0.002 & 0.510 \\
\hline 7 & B & 0.83 & 0.004 & 0.174 \\
\hline 8 & $"$ & 0.52 & 0.004 & 0.069 \\
\hline 9 & $"$ & 0.65 & 0.007 & 0.060 \\
\hline 10 & $"$ & 0.64 & 0.010 & 0.042 \\
\hline 11 & " & 0.24 & 0.002 & 0.028 \\
\hline 12 & $"$ & 0.45 & 0.008 & 0.026 \\
\hline 13 & " & 0.45 & 0.010 & 0.021 \\
\hline
\end{tabular}



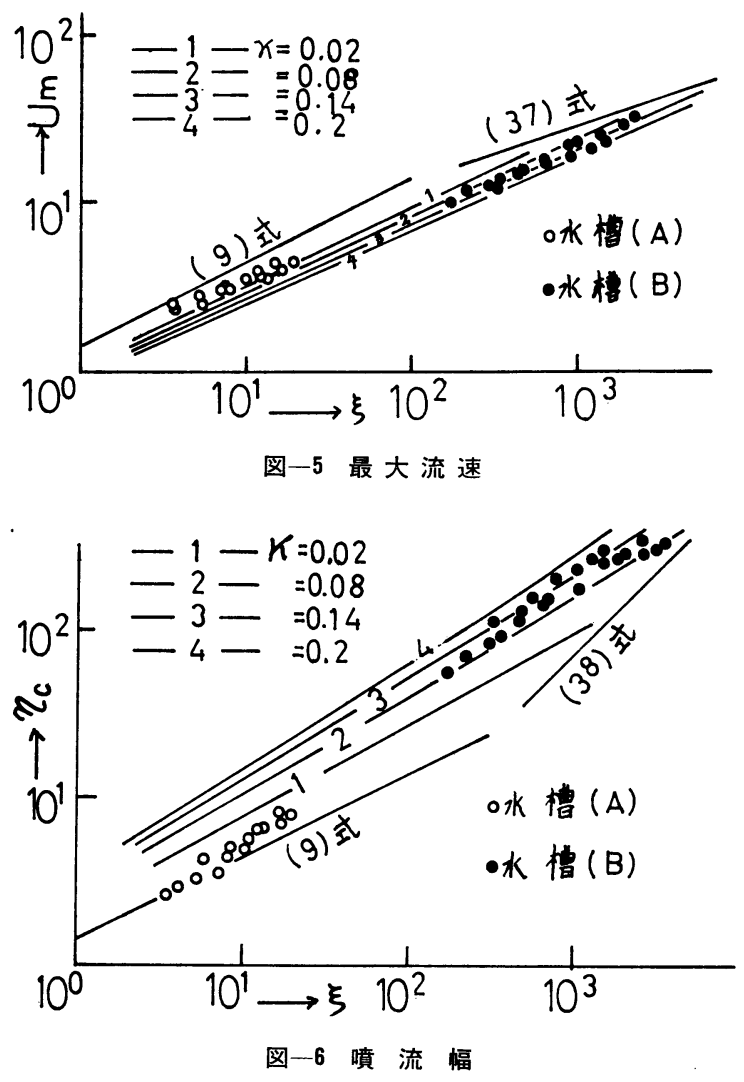

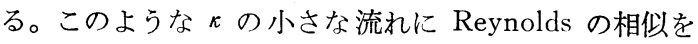
適用寸る明確な根拠はないが，流れは完全に乱流に遷移 しているので近似的に適用した。

水槽 $[\mathrm{A}]$ での実験結果は， $ぇ$ が 0.02 以下でむしろ 完全流体に近い状態となっている。これは, 渗出の影響 とともに流れの Reynolds 数が小さいため乱れが十分に 発達してないことにも起因している。

このことは, 密度界面の混合状態が, 渦が間久的に発 生する程度であることからも予想される。

水槽 $[\mathrm{B}]$ による実験では, $\kappa$ は 0.14 程度の值であ り, 密度界面も完全に乱れ, 流れの Reynolds 数の考虑 からも流れは完全に乱流状態であることを示す。

\section{(3) 流速分布}

図一7 から図一10 までは, 水槽 [A] で得られた流速 分布の実測值と, 理論解析により得られた值を比較して 示している。 $\xi$ が 10 以下の時は, 完全流体の解が実測 值と一致し， $\xi$ が 10 を越えると, むしろ乱流拡散を考 慮し， $\kappa=0.001$ とした時の解が実測值をよく説明して いる。このことは, 図一5 および図一6でもわかること であるが, $\xi$ が増加するにつれ，急速に乱流拡散の影響が 強まり完全流体とみなし得なくなることを示している。 一方, 図一11 から図一14 までは, 水槽 [B] で得ら

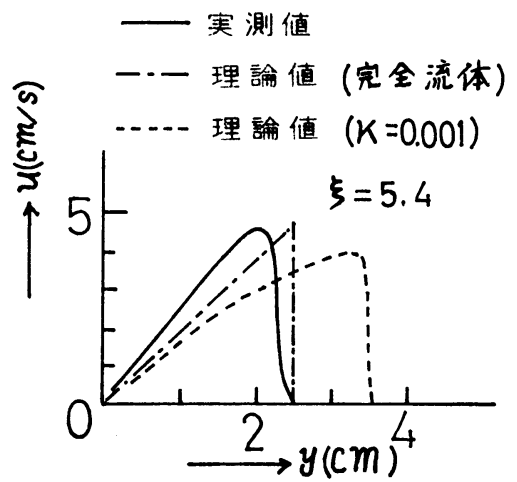

図一7 流速分布 $\xi=5.4$ (水槽 $[\mathrm{A}]$ )

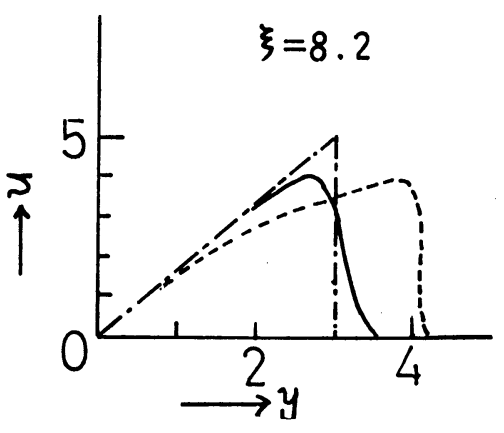

図-8 $\xi=8.2$

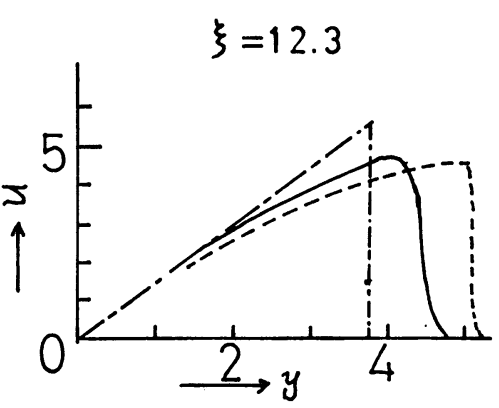

図一9 $\xi=12.3$

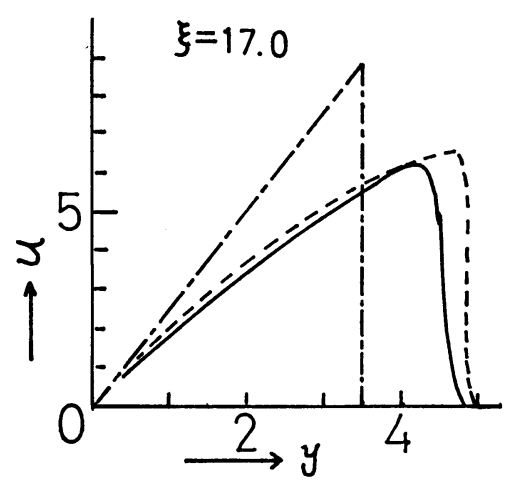

図-10 $\xi=17.0$ 
れた值と $\kappa=0.14$ としたときの理論值とを比較して示し ている。ほ が増加するにつれ最大流速の位置が壁面に接 近する様子が認められるが，多少理論值の方がより壁面 に接近する結果となっている。流速分布形の仮定 (13) が，実際の現象を説明するには多少の無理があるためと 考えられるが，実用上はこの程度の一致をみれば十分と いえる。

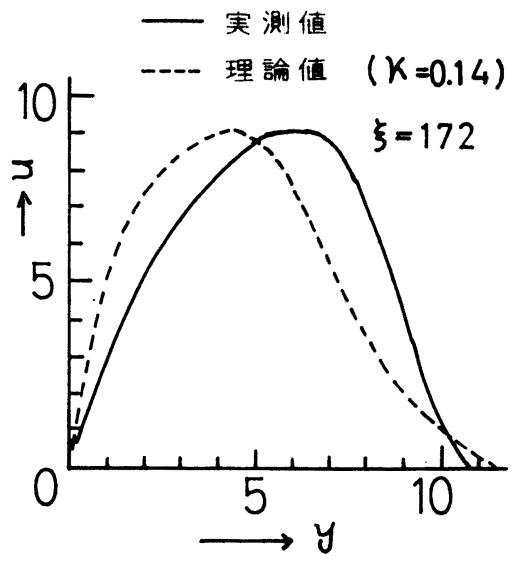

図一11 流速分布 $\xi=172$ (水槽 [B])

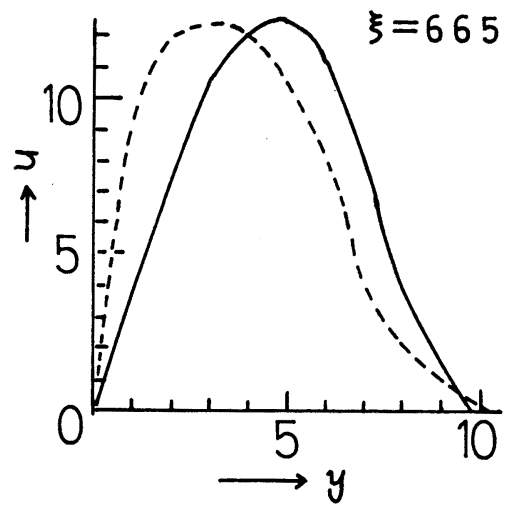

图-12 $\xi=665$

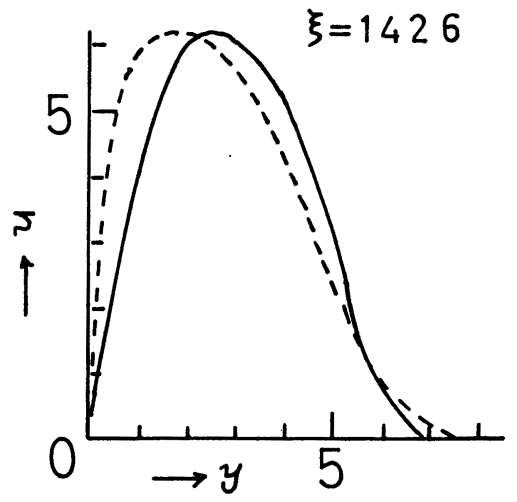

図-13 $\quad \xi=1426$

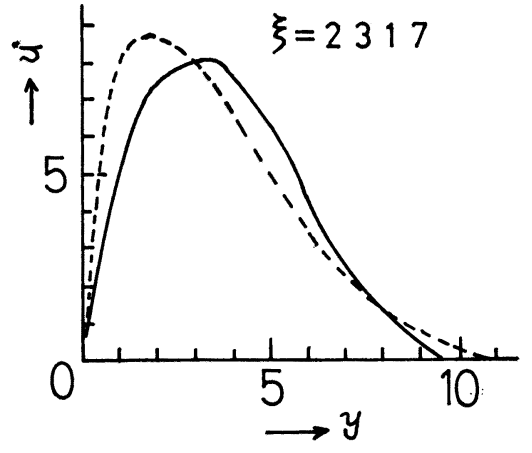

図-14 $\xi=2317$

\section{(3) 質量欠損分布}

水槽 [A] による実験では, 密度界面での混合は大き な渦が断続的に発生する程度であり, 密度界面近くまで 流入水の密度 $\rho_{w}$ が保たれているものと考えられる。こ こでは, 水槽 $[\mathrm{B}]$ での四電極伝導度計による質量欠損 分布の実測值と, $\kappa=0.14$ とした時の理論值が, 図一15 から 図一18 で比較されている。実測値の方がいくぶん

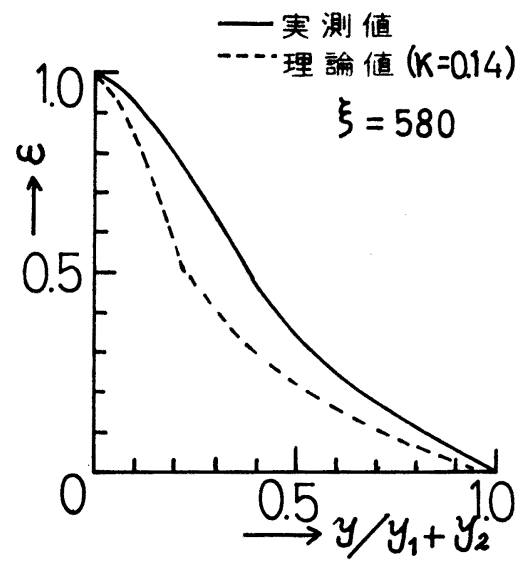

図一15 質量欠損分布 $\xi=580$ （水槽 [B]）

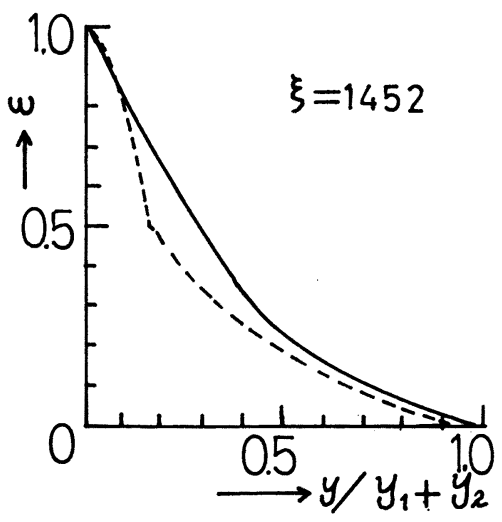

図-16 $\xi=1452$ 


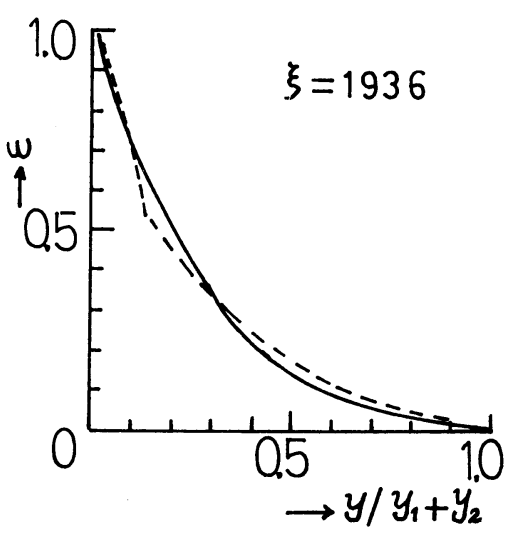

図-17 $\xi=1936$

大きな質量欠損分布を与えているが，(2) で実測值の最大 流速点がより壁面から離れていることに対応している。

式 (13) で仮定された質量欠損分布は, 最大流速点で 分布が不連続になり,かつ $\varepsilon=\varepsilon_{0} / 2$ となっているが,実用 上はこの程度の仮定で十分であることが同様にいえる。

\section{(4) 連行係数}

連続の式（12）は，噴流幅にわたって積分し連行係数 $E$ を使用すれば次式のように書ける。

$$
-\frac{\partial}{\partial x}\left(\int_{0}^{y_{c}} u d y\right)=E \frac{1}{y_{1}+y_{2}} \int_{0}^{y_{1}+y_{2}} u d y+v_{0} \cdots
$$

式（42）に分布形の仮定 式（13）を代入すれば,

$$
\begin{gathered}
\left(\frac{2}{\pi} y_{1}+\frac{1}{2} y_{2}\right) \frac{d u_{m}}{d x}+\frac{2}{\pi} u_{m} \frac{d y_{1}}{d x}+\frac{1}{2} u_{m} \frac{d y_{2}}{d x} \\
=E \frac{2 y_{1} / \pi+y_{2} / 2}{y_{1}+y_{2}} u_{m}+v_{0}
\end{gathered}
$$

となり，さらに式（21）を代入すれば，

$$
\begin{aligned}
\frac{E}{\kappa^{2}} & =\frac{\eta_{1}^{*}+\eta_{2} *}{2 \eta_{1}^{*} / \pi+\eta_{2} * / 2}\left[\left(\frac{2}{\pi} \eta_{1} *+\frac{1}{2} \eta_{2} *\right) \frac{d U^{*}}{d \xi^{*}}\right. \\
& \left.-\frac{2}{\pi} U * \frac{d \eta_{1} *}{d \xi^{*}}+\frac{1}{2} U^{*} \cdot \frac{d \eta_{2} *}{d \xi^{*}}-1\right] \ldots \cdots \cdots \cdots
\end{aligned}
$$

を得る。式 (22)，(23)，(24) の解析結果を式 (43) に 代入し， $\kappa$ をパラメーターにして連行係数 $E$ を表示す れば図一19 となる。同図には，水槽 [B]による実測結 果も同時に示している。

実測值は, 前述と同様に $\kappa=0.14$ の解析值の周辺に プロットされ， $\xi$ が増加するにつれ連行倸数 $E$ はしだ い減少している。図一19より，プリュームが上昇し $\xi$ が十分大きくなれば， $E$ は 0.1 漸近することがわか り,このことからも, 乱れが十分に発達した領域に执い て $E=0.1$ としてよいことがわかる。

\section{（5）壁面抵抗}

渗出のある固体壁の抵抗が渗出のない場合に比べて著

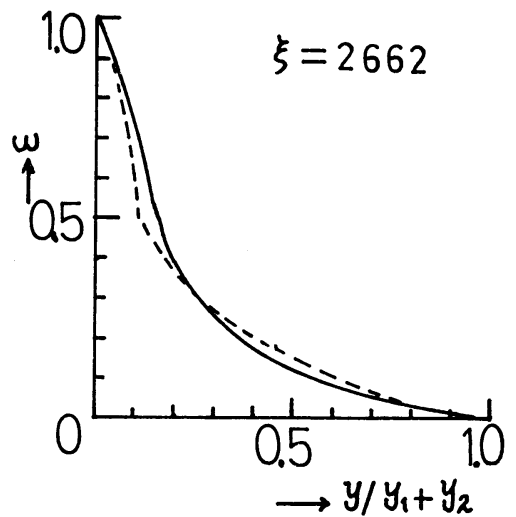

図-18 $\xi=2662$

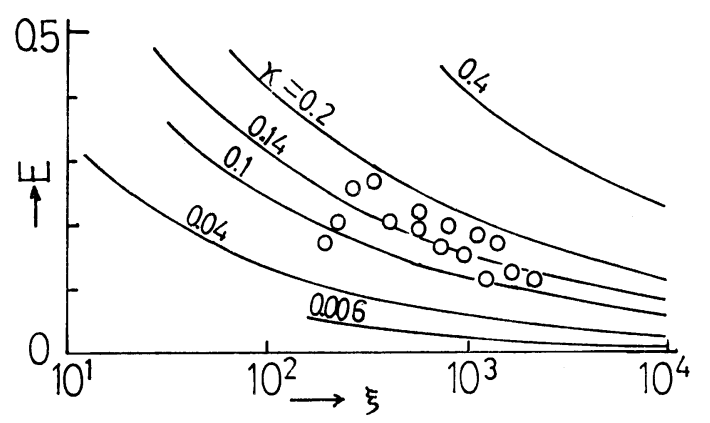

図-19連行 係 数

しく小さくなることは, 航空工学の分野でもかなり知ら れたことである ${ }^{6)}$ 。前述の解析において，壁面抵抗はす べて無視しているが, ここでは運動量の保存を考虑して 実験的にそのことを確かめる。

水槽 [A] では，流速分布が非常に完全流体に近く壁 面抵抗もきわめて小さいと考えられるので, 水槽 $[\mathrm{B}]$ に よる実験が考察の対象となる。

$x$ 方向の運動方程式は, せん断応力 $\tau$ を使用して次 式で与えられる。

$$
u \frac{\partial u}{\partial x}+v \frac{\partial u}{\partial y}=\varepsilon g+\frac{1}{\rho_{w}} \frac{\partial \tau}{\partial y}
$$

式（44）を連続の式（12）および境界条件 式（17）を 考虑し，噴流幅にわたって積分すれば，

$$
\frac{\partial}{\partial x}\left(\int_{0}^{y_{c}} u^{2} d y\right)=g \int_{0}^{y_{c}} \varepsilon d y-\frac{\tau_{w}}{\rho_{w}}
$$

ここに， $y_{c}$ は噴流幅で $\tau_{w}$ は壁面せん断応力である。 $\varepsilon_{m}$ を断面平均値とし, $\varepsilon_{m}=\beta \varepsilon_{0}$ とすれば, 式 (45) は,

$$
\tau_{w} / \rho_{w}=\beta \varepsilon_{0} y y_{c}-\frac{\partial}{\partial x}\left(\int_{0}^{y_{c}} u^{2} d y\right)
$$

となる。 $\beta$ の值は, 質量欠損の実測より 図一20に与え る。図一21 には, 実測値より求めた式 (46) の右辺第 1 


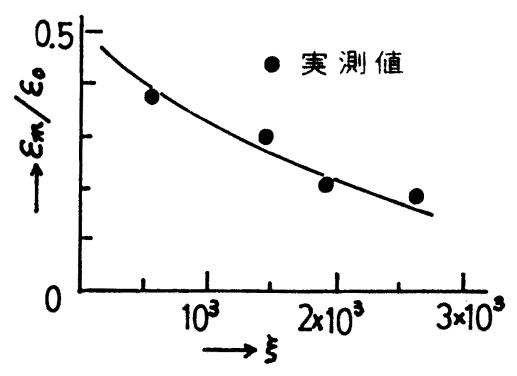

図一20 $\beta=\varepsilon_{m} / \varepsilon_{0}$ の決定

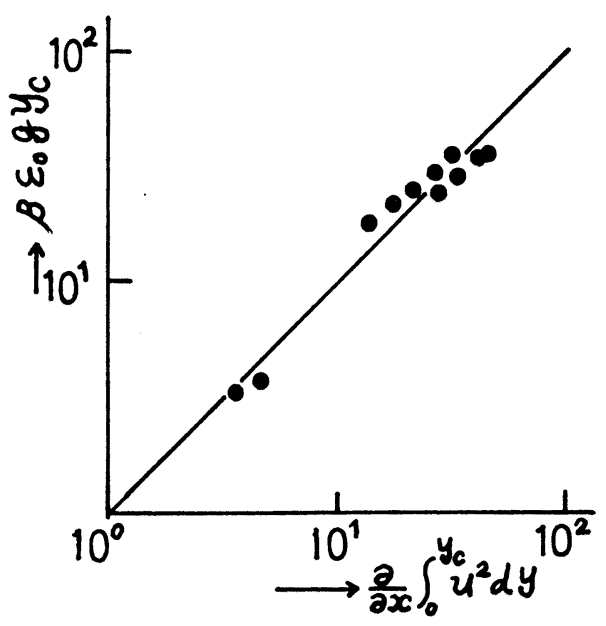

図一21 壁面せん断応力

項と第 2 項の関係を与えている。流速の測定精度を考え た時,きわめて粗い議論であるが, 実験でもほぼ壁面抵 抗は無視できると考えられる。

\section{4. むすび}

横流式沈殿池において, 流入水し池内水の温度差に起 因して発生する密度流に関して議論を進めてきたが，こ れにより整流壁を通り水槽底あるいは自由表面に衝突後 生ずる水平密度流の初期条件を確定できる。

解析において, 整流壁上の抵抗は無視している。この ことは，粗い議論であるが実測值によっても確かめら れ, Karman 定数が渗出のない境界層に比べて著しく減 少することからも説明される。

厳密にいえば, 流速分布および質量欠損分布の仮定に 多少の問題は残るけれども, 最大流速および噴流幅に関 してはこの程度の議論で十分説明できる。

本論文の理論計算には, 九州大学大型電子計算機 FACOM 230-60 を使用したこしを付記する。
記号説 明

$$
\begin{aligned}
& x: \text { 水槽底に沿って下流向きによった座標 } \\
& y: \text { 水槽底より鉛直上向きにとった座標 } \\
& u: \text { 流速の } x \text { 成分 } \\
& v: \text { 流速の } y \text { 成分 } \\
& v_{0}: \text { 一様流入流速 } \\
& p: \text { 圧力 }
\end{aligned}
$$$$
p_{b}: \text { 水槽底の压力 }
$$$$
o_{s}: \text { 池内水（塩水）の密度 }
$$$$
\rho_{w}: \text { 流入水（淡水）の密度 }
$$$$
\rho: フ^{y} \text { ューム内の密度 }
$$$$
\varepsilon:\left(\rho_{s}-\rho\right) / \rho_{w}
$$$$
\varepsilon_{0}:\left(\rho_{s}-\rho_{u^{\prime}}\right) / \rho_{u}
$$$$
\psi: \text { 流関数 }
$$

$y_{1}$ : 整流壁面より最大流速点までの距離 $y_{2}$ : 最大流速点より密度界面までの距離 $y_{c}:$ 噴流幅 $\left(y_{c}=y_{1}+y_{2}\right)$

$u_{m}:$ 最大流速

$u_{1}: 0<y<y_{1}$ にお污流速の $x$ 成分 $u_{2}: y_{1}<y<y_{1}+y_{2}$ における流速の $x$ 成分 $v_{1}: 0<y<y_{1}$ における流速の $y$ 成分 $v_{2}: y_{1}<y<y_{1}+y_{2}$ における流速の $y$ 成分 $\varepsilon_{1}: 0<y<y_{1}$ に拈ける $\varepsilon$ の值 $\varepsilon_{2}: y_{1}<y<y_{1}+y_{2}$ における $\varepsilon$ の值

$$
\begin{array}{rlrl}
\kappa & : \text { Karman 定数 } & g & : \text { 重力加速度 } \\
\xi & : \varepsilon_{0} g x / v_{0}^{2} & \xi^{*} & : \kappa^{4} \varepsilon_{0} g x / v_{0}^{2} \\
\eta & : \varepsilon_{0} g y / v_{0}^{2} & \eta_{c} & : \varepsilon_{0} g y_{c} / v_{0}^{2} \\
\eta_{1}{ }^{*} & : \kappa^{2} \varepsilon_{0} g y_{1} / v_{0}^{2} & \eta_{2}{ }^{*} & : \kappa^{2} \varepsilon_{0} g y_{2} / v_{0}^{2} \\
U & : u / v_{0} & U_{m}: u_{m} / v_{0} \\
U^{*}: \kappa^{2} u / v_{0} & V: v / v_{0}
\end{array}
$$

$E:$ 連行係数

$c_{1}, c_{2}$ : 流速および質量欠損分布形により決まる定数

$\tau:$ せん断応力 $\beta: \varepsilon_{m} / \varepsilon_{0}$

$\tau_{w}:$ 壁面せん断応力

\section{参考 文 献}

1) Fisherstrom, N.H. : Proc. of A.S.C.E. Vol. 81, p. $687,1955$.

2）中川義德：水道協会雑誌，No. 333, p. 28 , 昭 37 .

3）中川義徳：水道協会雑誌, No. 258 , p. 9, 昭 31 .

4）粟谷陽一・楠田哲也：土木学会論文集, Vol. 168, p. 25, 1966.

5）甲藤好郎：伝熱概論, p. 137, 養賢堂, 1972.

6) Dorrance, W.H. and Dore, F.J. : Journal of Aeronautical Sciences, Vol. 21, p. 404, 1954.

7）椿東一郎・小松利光 : 第 28 回士木学会年次学術講演会概 要集, p. 359 , 昭 48 .

(1975. 3. 17 . 受付) 